\title{
Pendidikan Karakter Anak Usia Dini melalui Sentra Bahan Alam
}

\author{
Kartika Ayu Ningsih ${ }^{1}$, lis Prasetyo${ }^{1}$, Dwi Fitria Hasanah ${ }^{1 凶}$ \\ Pendidikan Anak Usia Dini, Universitas Negeri Yogyakarta, Indonesia(1) \\ DOI: $10.31004 /$ obsesi.v6i1.1172
}

\begin{abstract}
Abstrak
Pendidikan karakter mengajarkan siswa tentang nilai-nilai dasar kemanusiaan diantaranya kebaikan, kejujuran, keberanian, menghargai, kesetaraan dan kemurahan hari. Tujuan dari penelitian ini untuk mengetahui implementasi pilar pendidikan karakter berbasis Sentra Alam PAUD Fatma Kenanga di Bengkulu. Menggunakan metode kualitatif deskriptif. Menggunakan sampel target untuk mengidentifikasi peserta studi. Menggunakan teknik pengumpulan data berupa wawancara terstruktur, observasi non partisipan dan dokumentasi. Teknik analisis data yang digunakan meliputi reduksi data, representasi data dan grafik kesimpulan. Teknik validitas dan reliabilitas menggunakan triangualasi sumber, teknik dan waktu. Hasil penelitian menunjukkan sembilan pilar kepribadian diterapkan dengan pendekatan berorientasi aktivitas melalui kebiasaan sehari-hari dan aktivitas sentral, serta diterapkan langsung dari media alam. Pelaksanaan pilar pendidikan karakter memerlukan fasilitas yang memadai, tenaga pendidik adalah lulusan PAUD, antusias siswa yang tinggi, dan kerjasama dengan orang tua.
\end{abstract}

Kata Kunci: pendidikan karakter; sentra alam; paud

\begin{abstract}
Character education is teaching students about the basic values of humanity including goodness, honesty, courage, respect, equality and generosity of the day. The purpose of this study was to determine the implementation of the pillars of character education based on the Sentra Alam PAUD Fatma Kenanga in Bengkulu. This research uses descriptive qualitative method. Use a target sample to identify study participants. The data collection techniques used were structured interviews, non-participant observation and documentation. The data analysis technique used includes data reduction, data representation and conclusion graphs. The validity and reliability techniques use triangualation of sources, techniques and time. Based on the analysis carried out, the implementation of the nine pillars of personality are applied with an activity-oriented approach through daily habits and central activities, and are applied directly from natural media. After that, there will be a daily, weekly and monthly evaluation. The implementation of the character education pillar requires adequate facilities, the teaching staff is PAUD graduates, high student enthusiasm, and cooperation with parents.
\end{abstract}

Keywords: character education; natural center; paud

Copyright (c) 2021 Kartika Ayu Ningsih, et al.

$\triangle$ Corresponding author :

Email Address : kartikaayu.2019@student.uny.ac.id (Yogyakarta, Indonesia)

Received 1 Maret 2021, Accepted 1 April 2021, Published 18 August 2021 


\section{PENDAHULUAN}

Pendidikan adalah hal yang sangat penting untuk diperoleh semua individu karena pendidikan merupakan salah satu modal yang harus dimiliki oleh setiap individu untuk meraih kesuksesan dalam hidupnya. Pendidikan memberikan pengaruh dan kontribusi yang sangat besar bagi pengembangan diri individu. Pendidikan dipahami sebagai suatu tindakan yang dilakukan dengan sengaja oleh seorang pendidik guna mencapai tujuan yang telah ditentukan, atau mencapai kondisi yang lebih baik bagi individu. Undang-Undang No. 20 Tahun 2002 Pasal 9 Ayat 1 tentang Perlindungan Anak dinyatakan bahwa: Setiap anak berhak memperoleh pendidikan dan pendidikan dalam rangka pengembangan pribadinya dan tingkat kecerdasannya sesuai dengan minat dan bakatnya. Anak usia dini sejak lahir sampai enam tahun merupakan usia yang sangat menentukan dalam pembentukan karakter dan kepribadian seorang anak. Usia itu sebagai usia penting bagi pengembangan inteligensi permanen dirinya, mereka juga mampu menyerap informasi yang sangat tinggi.

Menurut Mukhtar Latif (2013) Pusat Bahan Alam merupakan pusat yang memberikan kesempatan kepada anak-anak untuk berinteraksi langsung dengan berbagai bahan untuk mendukung sensorimotor, pengendalian diri, dan ilmu pengetahuan, menurut Suyadi \& Dahlia (2014) Pusat Bahan Alam bertujuan memberikan kesempatan kepada anak-anak untuk mengeksplorasi berbagai materi yang ada di alam. Kegiatan yang bisa dilakukan adalah mencampurkan warna, memancing, mengayun dan menancapkan benih (Kementerian Pendidikan dan Kebudayaan, 2013). Pusat Bahan Alam bertujuan untuk memberikan pengalaman kepada anak-anak dalam mengeksplorasi berbagai materi. Di pusat ini, anakanak bermain dan belajar mendemonstrasikan kemampuan untuk menunjukkan, mengenali, membandingkan, menghubungkan dan membedakan. Melalui eksplorasi dan eksperimen, anak akan memiliki ide dan kepekaan terhadap pengetahuan dan lingkungan alam, sehingga meningkatkan motivasi dan kepercayaan diri mereka dalam belajar.

Menurut Firmadani (2020) Manusia tidak lepas dari pendidikan, di dalam keluarga, masyarakat, terlebih lagi sekolah, kita dapat menemukan suatu pendidikan. Pendidikan dalam keluarga, pendidikan yang pertama kali didapat oleh seseorang yaitu penanaman nilai, etika, moral, dan akhlak, sejak dia lahir ke dunia sehingga pendidikan yang ditanamkan oleh keluarga sejak kecil akan menjadi karakter anak tersebut.

Menurut Suyanto Asmani (2011) berpendapat bahwa pendidikan karakter adalah pendidikan karakter plus, yang melibatkan semua aspek pengetahuan (kognisi), perasaan (feeling), dan tindakan (tindakan). Pada kesempatan yang sama Masnur Muslich (Muslich, 2011) menyampaikan bahwa pendidikan karakter merupakan suatu sistem bagi warga sekolah untuk memahami nilai-nilai karakter yang meliputi pengetahuan, kesadaran, kemauan, dan tindakan yang dilakukan untuk mewujudkan nilai-nilai tersebut.Komponen tersebut antara lain Tuhan Yang Maha Esa (YME), bertetangga dengan dirinya sendiri. Lingkungan dan kebangsaan yang menjadikan mereka manusia.

Dalam hubungannya dengan pendidikan karakter, terdapat nilai-nilai luhur yang menjadi karakter, diantaranya: (1) domain pikir mencakup karakter-karakter seperti cerdas, kritis, kreatif, inovatif, ingin tahu, berfikir terbuka, produktif, berorientasi Iptek, dan reflektif, (2) domain hati mencakup karakter-karakter untuk beriman dan bertakwa, jujur, amanah, adil, bertanggungjawab, berimpati, berani, mengambil resiko, pantang menyerah, rela berkorban, dan berjiwa patriotik, (3) domain raga mencakup karakter-karakter seperti bersih dan sehat, disiplin, sportif, tangguh, andal, berdayatahan, bersahabat, kooperatif, determinatif, kompetetif, ceria, dan gigih, (4) domain rasa meliputi karakter-karakter seperti ramah, saling menghargai, toleran, peduli, suka menolong, gotong royong, nasionalis, kosmopolit, mengutamakan kepentingan umum, dinamis, kerjasama, dan beretos kerja. Towoliu et al. (2020) menyebutkan nilai-nilai etika inti yaitu antara lain rasa hormat, peduli, jujur, toleransi dan berbagi. Lee (2016) menjelaskan Semua aspek perkembangan merupakan capaian dan tujuan dari kegiatan pembelajaran di PAUD. Proses pembelajaran di di PAUD menekankan semua aspek perkembangan berhasil dalam perkembangan anak usia dini 
Pendidikan Anak Usia Dini Fatma Kenanga yang terletak di Jalan Flamboyan 23 No. 49 Skip Ujung Kota Bengkulu. Lembaga ini merupakan lembaga pertama di Provinsi Bengkulu yang menekankan pada pembentukan karakter anak yang berlandaskan pada nilainilai islami. PAUD Fatma Kenanga, sebagai lembaga pendidikan islam yang menangani anak usia dini dapat memberikan sumbangsih kepada calon generasi islam yakni dengan menciptakan lingkungan yang kondusif dan menyenangkan bagi anak untuk belajar banyak hal, dengan tetap memegang prinsip pokok pembelajaran yaitu peletakkan dasar keimanan yang kuat pada anak, membangun budaya pada diri anak agar memiliki semangat tinggi dalam mencari ilmu dan membiasakan anak berakhlaq mulia sejak dini.

Proses pembelajaran di PAUD menekankan semua aspek perkembangan berhasil dalam perkembangan anak usia dini (Ramdhani, 2019). Konsep pembelajaran yang dilaksanakan di PAUD Fatma Kenanga adalah konsep Pendidikan Holistik Berbasis Karakter yang didasarkan pada Pembelajaran Anak Usia Dini Selaras Perkembangan (Developmentally Appropiate Practice). Konsep pembelajaran ini dipakai dengan menggabungkan metode BCCT (Beyond Center and Circle Time) melalui kegiatan sentra di integrasikan dengan pendidikan karakter yang mengajarkan sembilan pilar karakter yakni (1) CintaTuhan dan Segenap ciptaan-Nya, (2) Tanggungjawab, Kedisiplinan, dan Kemandirian, (3) Kejujuran, Amanah, dan Diplomatis, (4) Hormat dan Santun, (5) Kasihsayang, Kepedulian, danKerjasama, (6) Percayadiri, Kreatif, Kerjakeras, dan Pantang menyerah, (7) Keadilan dan Kepemimpinan, (8) Baik dan Rendah hati, (9) Toleransi, Cinta damai, dan Persatuan.

Kegiatan sentra dipadukan dengan pembelajaran karakter sesuai dengan jadwal sentra dan pilar karakter. Sistem sentra adalah pengelolaan kelas yang terpusat pada suatu kegiatan dan ditangani oleh satu guru secara khusus. Ada 6 sentra yang diterapkan di PAUD Karakter Fatma Kenanga, diantaranya: Sentra Main Peran, Sentra Persiapan, Sentra Seni, Sentra Balok, Sentra Imtaq dan Sentra Bahan Alam. Setiap sentra mendukung perkembangan anak dalam tiga jenis bermain, yaitu bermain sensori motor atau fungsional, bermain peran, dan bermain konstruktif (membangun pemikiran anak).

Pada penelitian Febriana Budiarti dengan judul Analisis Pembelajaran Sentra Bahan Alam Untuk Mengembangkan Kreativitas Menempel Anak Usia 5-6 Tahun yang bertujuan untuk mendeskripsikan perencanaan, pelaksanaan, media, metode yang digunakan, serta kendala yang dihadapi guru dalam menerapkan pembelajaran sentra bahan alam untuk mengembangkan kreativitas menempel anak usia 5-6 tahun di ra al-iman pontianak. Penelitian ini menggunakan metode deskriptif dengan pendekatan kualitatif. Sampel penelitian ini adalah 1 guru sentra bahan alam dan anak kelompok b. Hasil analisis data menunjukkan bahwa perencanaan dan pelaksanaan yang dilakukan guru cukup baik. Adapun kesulitan yang dialami guru dalam pembelajaran sentra bahan alam adalah guru kurang menyiapkan media pembelajaran dan kondisi anak yang tidak baik sehingga anak tidak mau melakukan kegiatan menempel. Upaya yang dilakukan guru dalam menghadapi masalah tersebut adalah sehari sebelum melakukan pembelajaran, guru terlebih dahulu mempersiapkan media pembelajaran yang akan digunakan dan peserta didik yang tidak mau melakukan kegiatan menempel di bujuk, dan diberikan waktu sendiri untuk menyelesaikan kegiatan menempel menggunakan bahan alam (Budiarti, 2015)

Sentra bahan alam merupakan pusat pembelajaran dari sentra yang lain karena sentra bahan alam menggunakan panca indra secara langsung, melatih motorik, kognitif, sosial, dan emosi sehingga proses pembelajaran lebih efektif. Sentra bahan alam ini memfasilitasi anak untuk mengembangkan dan memperluas pengalaman bermain sensori motor dengan memberikan banyak kesempatan pada anak untuk mengeksplorasi bahan-bahan alami dalam mengembangkan kematangan motorik halus yang diperlukan dalam proses kesiapan menulis, keterampilan berolahtangan, dan menstimulasi sistem kerja otak anak. Menurut (Iswantiningtyas, 2019) Sentra bahan alam memberikan kesempatan untuk membangun 
kemampuan dengan berbagai macam bahan atau dengan bahan-bahan yang berbeda. Selain itu juga memberikan kesempatan anak mendapatkan pengalaman sensori-motor yang kaya dan mampu membangun kontrol diri.

\section{METODOLOGI}

Penelitian ini menggunakan metode kualitatif dengan pendekatan deskriptif. Penelitian ini bertujuan untuk menggambarkan dan menganalisa apa yang terjadi di lapangan sesuai apa adanya yang berupa kata-kata dan gambar. Sasaran pada penelitian ini adalah anak usia dini yang ada di PAUD Fatma Kenanga. Teknik pengumpulan data dalam penelitian ialah wawancara terstruktur, observasi nonpartisipan, dan dokumentasi. Partisipan dalam penelitian ini ialah Ibu Keapala Sekolah, Pendidik Sentra Bahan Alam dan 4 orang tua peserta didik di lemabaga teserbut.

Penelitian ini dilakukan di Penelitian ini dilaksanakan di PAUD Fatma Kenanga Kota Bengkulu yang terletak di Jalan Flamboyan 23 No. 49 Skip Ujung RT. 06 RW. 01 Kelurahan Kebun Kenanga Kecamatan Ratu Agung Kota Bengkulu. Dalam penelitian ini yang menjadi instrumen atau alat penelitian adalah peneliti itu sendiri.

Dalam hal ini, Moleong (Basrowi \& Suwandi, 2008) memaparkan bahwa penelitian kualitatif antara lain bersifat deskriptif, data yang dikumpulkan lebih banyak berupa katakata atau gambar daripada angka-angka. Selanjutnya setelah fokus penelitian menjadi jelas, maka kemungkinan akan dikembangkan instrumen penelitian sederhana yang diharapkan dapat melengkapi data dan membandingkan dengan data yang telah ditemukan melalui observasi dan wawancara (Sugiyono, 2006). Dalam analisis data adapun langkah-langkahnya yaitu : Reduksi data, penyajian data, verifikasi data. Teknik validasi dan reliabelitasnya menggunakan trianggulasi.

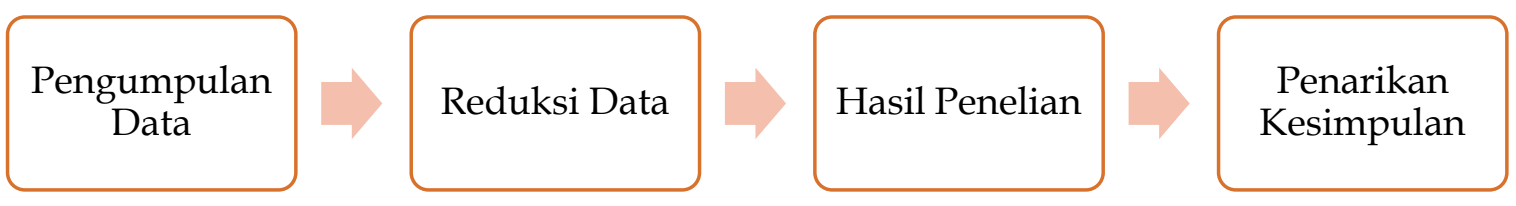

Gambar 1. Tahapan penelitian

\section{HASIL DAN PEMBAHASAN}

Penelitian dilaksanakan di PAUD Fatma Kenanga Kota Bengkulu. Peneliti melakukan wawancara dengan guru-guru sentra bahan alam, menyusul pedoman observasi, dokumentasi dan catatan lapangan

\section{Perencaan}

Berdasarkan hasil wawancara perencanaan pembelajaran dalam pembekalan ialah hal yang sangat penting untuk dilakukan. Perencanaan pilar pendidikan karakter berbasis bahan alam pada play group PAUD Fatma Kenanga Kota Bengkulu dengan menyusun program tahunan, program semesteran, program mingguan (RPPM), dan program harian (RPPH) secara bersama-sama yang mengacu pada kurikulum 2013. Perencanaan pembelajaran dilakukan per tema sesuai dengan tahap perkembangan anak. Tema yang dipilih berdasarkan hal-hal yang terdekat dengan anak. Kemudian pendidik mempersiapkan apa yang diperlukan dan melakukan pijakan lingkungan main, pijakan pengalaman sebelum main, pijakan pengalamaan saat main dan pijakan pengalaman setelah main. Hal ini senada dengan yang disampaikan oleh (Rusman, 2014) bahwa: Tahap perencanaan guru dalam kegiatan pembelajaran adalah tahap yang akan berhubungan dengan kemampuan guru menguasai bahan ajar.

Kemampuan guru dalam hal ini dapat dilihat dari cara atau proses penyusunan program kegiatan pembelajaran yang dilakukan oleh guru. Penerapan pilar pendidikan karakter berbasis bahan alam pada play group dilaksanakan satu kali dalam satu minggu. 
Pelaksanaannya setiap hari Selasa dikarenakan pada PAUD Fatma Kenanga ini menggunakan sistem moving class. Jadi setiap kelas mendapat giliran satu kali dalam satu minggu untuk bermain sentra. Menurut (Rusman, 2014), Alokasi waktu ditentukan sesuai dengan keperluan untuk pencapaian kompetensi dasar dan beban belajar.

PAUD Fatma Kenanga Kota Bengkulu terdapat sembilan pilar pendidikan karakter yang diterapkan. Pilar pendidikan karakter yang diambil dari sikap Asmaul Husna, diantaranya: 1) Cinta Tuhan dan Segenap ciptaan-Nya, 2) Tanggung jawab, Kedisiplinan, dan Kemandirian, 3) Kejujuran, Amanah, dan Diplomatis, 4) Hormat dan Santun, 5) Kasih sayang, Kepedulian, dan Kerjasama, 6) Percaya diri, Kreatif, Kerja keras, dan Pantang menyerah, 7) Keadilan dan Kepemimpinan, 8) Baik dan Rendah hati, 9) Toleransi, Cinta damai, dan Persatuan. Hal ini sependapat dengan (Zainal Aqib \& Ahmad Amrullah, 2017), bahwa:Terdapat 18 nilai-nilai pembentuk karakter yang bersumber dari agama, pancasila, budaya, dan tujuan pendidikan nasional, yaitu: (1) Religius, (2) Jujur, (3) Toleransi, (4) Disiplin, (5) Kerja Keras, (6) Kreatif, (7) Mandiri, (8) Demokratis, (9) Rasa Ingin Tahu, (10) Semangat Kebangsaan, (11) Cinta Tanah Air, (12) Menghargai Prestasi, (13) Bersahabat/Komunikatif, (14) Cinta Damai, (15) Gemar Membaca, (16) Peduli Lingkungan, (17) Peduli Sosial, dan (18) Tanggung Jawab. Kemudian, M. Yaumi (2014: 83) juga menjelaskan bahwa nilai-nilai budaya dan karakter bangsa sebagaimana pada tabel 1 (lampiran).

\section{Proses Penerapan Pilar Pendidikan Karakter}

Karakter merupakan sifat, watak, ataupun hal-hal mendasar yang terdapat pada diri seseorang dan menjadi pembeda dengan orang lain (Prasetyo, 2011), Karakter yang baik berkaitan dengan mengetahui yang baik (knowing the good), mencintai yang baik (loving the good), dan melakukan yang baik (acting the good)(Sudrajat, 2011). Karakter terbentuk menjadi bawaan seseorang, namun dari hasil interaksi dengan sekitar, karakter juga dapat dipengaruhi oleh berbagai faktor, termasuk dari lingkungannya. Sedangkan menurut (Rasyad, 2015) Pendidikan karakter hadir dalam dunia pendidikan tentu dengan harapan dapat memberikan berbagai pengalaman nyata yang dapat membawa seseorang memiliki karakter yang baik. menjelaskan bahwa pengembangan nilai karakter merupakan aspek yang terkait dengan tingkat pengendalian diri yang dapat diberikan seorang individu dengan menampilkan perilaku internal atau eksternal yang dikontrol secara eksternal mengenai nilai-nilai universal di dalam masyarakat.

Proses penerapan pilar pendidikan karakter berbasis bahan alam pada play group dilakukan melalui pembiasaan sehari-hari. Ada empat pijakan proses penerapan pilar pendidikan karakter berbasis bahan alam yang terdiri dari pijakan lingkungan main, pijakan pengalaman sebelum main, pijakan pengalaman saat main, dan pijakan pengalaman setelah main. Pada pijakan lingkungan main, pendidik menata lingkungan kegiatan dengan menyediakan dan menyiapkan tempat serta bahan-bahan yang akan digunakan untuk bermain. Pada pijakan pengalaman sebelum main, pendidik memulai kegiatan dengan menyapa peserta didik seperti mengucapkan salam, menanyakan kabar peserta didik, menanyakan tanggal dan bulan, mendiskusikan tema dan kegiatan yang akan dilakukan, pendidik juga menjelaskan prosedur main dan waktu main. Pada pijakan pengalaman saat main, peserta didik diberi kesempatan untuk memilih teman sekelompoknya dan diberi kebebasan untuk memilih kegiatan. Setelah selesai kegiatan pertama, peserta didik diarahkan untuk melanjutkan pada kegiatan kedua, ketiga, dan seterusnya, saat anak bermain pendidik berkeliling untuk mengamati bagaimana proses main anak kemudian mendokumentasikan perkembangan dan kemajuan main anak. Pada pijakan pengalaman setelah main. Peserta didik melakukan recalling, ketika recalling itu pendidik menanyakan apa yang sudah 
dilakukan peserta didik, pendidik mendukung peserta didik untuk mengingat kembali pengalaman mainnya dan saling menceritakan pengalaman mainnya. Kemudian peserta didik membereskan bahan-bahan main yang telah dilakukan.

Hal ini sesuai dengan teori Yuliani Nurani Sujiono dan Bambang (Sujiono, 2010) langkah-langkah kegiatan disentra bahan alam, sebagai berikut: (1) Guru menyiapkan alat atau bahan yang akan dimainkan. (2) Anak-anak dikumpulkan dan guru menerangkan alat atau bahan yang akan digunakan serta aturan bermain di sentra. (3) Guru memeriksa kehadiran anak dan memberi tahu nama kelompok mereka. (4) Guru bersama-sama anak menghitung jumlah murid yang hadir. (4) Guru memberitahukan alat-alat yang dipergunakan. (5) Guru memberitahu aturan-aturan di sentra. (6) Guru mempersilakan anak untuk bermain. (7) Anak memilih alat/bahan sesuai dengan keinginan mereka (anak diberi kesempatan untuk memilih). (8) Guru mengawasi anak-anak yang sedang melakukan kegiatan dan mendatangi setiap kelompok serta mengadakan komunikasi jika diperlukan. (9) Anak selesai membuat sesuatu, hasilnya ditunjukkan kepada guru, guru dengan penuh perhatian dan memuji hasil karya anak. (10) Kadang-kadang guru melihat dengan kegiatan anak. Contoh: anak-anak sedang menyikat lantai, guru menuangkan airnya dari atas, dan guru mengisi lagi tempat air yang kosong. (11) Guru siap membantu anak jika diperlukan. (12) Guru menulis nama dan tanggal pada hasil karya anak (hasil melukis dengan cat, menggambar) serta langsung memasang hasil karya pada tempat yang telah disediakan. (13) Selesai kegiatan guru bersama-sama anak membereskan alat permainan.

\section{Metode dalam Penerapan Pilar Pendidikan Karakter}

Menurut Sudjana (2005) metode pembelajaran ialah cara yang dipergunakan guru dalam mengadakan hubungan dengan siswa pada saat berlangsungnya pengajaran. Metode pembelajaran dapat diartikan sebagai cara yang digunakan untuk mengimplementasikan rencana yang sudah disusun dalam bentuk kegiatan nyata dan praktis untuk mencapai tujuan pembelajaran. Sedangkan menurut Sobri Sutikno (2009) menyatakan "metode pembelajaran adalah cara-cara menyajikan materi pelajaran yang dilakukan oleh pendidik agar terjadi proses pembelajaran pada diri siswa dalam upaya untuk mencapai tujuan", kemudian menurut (Retnowati, 2008) metode pembelajaran yang efektif adalah metode yang mendorong siswa untuk membangun pengetahuan dengan baik, sehingga dapat menggunakannya unutk menyelesaikan masalah baru. Berdasarkan uraian di atas, dapat disimpulkan bahwa metode pembelajaran merupakan suatu cara yang dilakukan oleh seorang guru agar terjadi proses belajar pada diri siswa untuk mencapai tujuan.

Metode yang digunakan dalam penerapan pilar pendidikan karakter berbasis bahan alam pada play group diantaranya: metode ceramah, metode praktek langsung, metode eksperimen. Metode yang digunakan disesuaikan dengan kegiatan yang akan dilakukan. Menurut Wina Sanjaya (2011) Metode adalah cara yang digunakan untuk mengimplementasikan rencana yang sudah disusun dalam kegiatan nyata agar tujuan yang telah disusun tercapai secara optimal. Selanjutnya, dijelaskan oleh Nana Sukmadinata (Rusman, 2014) bahwa pada penggunaan metode pembelajaran guru diharapkan mampu memilih dan menggunakan metode pembelajaran sesuai dengan materi yang akan disampaikan.

\section{Media dalam Penerapan Pilar Pendidikan Karakter}

Media yang digunakan dalam penerapan pilar pendidikan karakter berbasis bahan alam pada play group yaitu bahan-bahan yang berasal dari alam langsung seperti pasir kinestik, tanah, batu-batuan, air, pupuk, sampah, kerang-kerangan, biji-bijian, buah, pewarna makanan, tepung, sagu, daun-daun, dan sabun. Menurut R. Ibrahim dan Nana Syaodih S dalam (Rusman, 2014), Media pembelajaran dalam proses pembelajaran digunakan untuk membantu didalam kegiatan belajar dan mengajar serta dapat membantu memberikan pengalaman konkret, memotivasi dan membangkitkan minat belajar anak (Liyana, 2019). 
Media adalah sesuatu yang dapat digunakan untuk menyalurkan pesan (materi pembelajaran), merangsang pikiran, perasaan, perhatian, dan kemampuan siswa, sehingga dapat mendorong proses pembelajaran. Selain itu juga, Yuliani Nurani Sujiono dan Bambang (Sujiono, 2010), menjelaskan alat permainan yang digunakan di sentra bahan alam, diantaranya dapat dilihat pada tabel 2 (lampiran).

\section{Evaluasi dalam Penerapan Pilar Pendidikan Karakter}

Evaluasi yang dilakukan dalam penerapan pilar pendidikan karakter berbasis bahan alam pada play group ada tiga tahap. Pertama, evaluasi harian. Evaluasi ini dilakukan melalui pengamatan langsung ketika peserta didik belajar dan saat recalling, kemudian proses kegiatannya dicatat di catatan harian peserta didik dan diceklist perkembangan peserta didik. Kedua, evaluasi mingguan. evaluasinya menggunakan indeks penilaian BB (Belum Berkembang, MB (Mulai Berkembang), BSH (Berkembang Sesuai Harapan), BSB (Berkembang Sangat Baik) untuk mengetahui peserta didik ada di tahap mana. Ketiga, evaluasi bulanan menggunakan laporan perkembangan bulanan yang merupakan hasil akumulasi dari evaluasi harian dan mingguan. Seperti yang dijelaskan oleh Rusman, (2014) bahwa: Evaluasi adalah kegiatan atau cara yang ditujukan untuk mengetahui tercapai atau tidaknya tujuan pembelajaran dan juga proses pembelajaran yang telah dilakukan. pada tahap ini seorang guru dituntut memiliki kemampuan dalam menentukan pendekatan dan cara-cara evaluasi, penyusunan alat-alat evaluasi, pengolahan dan penggunaan hasil evaluasi.Hal ini juga dipaparkan oleh (Sutarjo \& Adisusilo. J.R... 2014) bahwa"Evaluasi merupakan proses pengumpulan, pelaporan, dan penggunaan informasi tentang hasil belajar siswa yang diperoleh melalui pengukuran untuk menganalisis unjuk kerja atau prestasi siswa dalam mengerjakan tugas-tugas yang terkait. Kemudian, (Wina Sanjaya, 2011)menjelaskan bahwa evaluasi bukan saja berfungsi untuk melihat keberhasilan siswa dalam proses pembelajaran, tetapi juga berfungsi sebagai umpan balik bagi guru atas kinerjanya dalam pengelolaan. Peserta didik dapat menerapkan pilar pendidikan karakter dalam kehidupan sehari-harinya. Selengkapnya dapat dilihat pada tabel 3 (lampiran).

Hal ini senada dengan teori Marzuki dalam (Dwi Riyanti Danang Prasetyo, 2019), bahwa agar nilai-nilai karakter bisa diterapkan dalam kehidupan sehari-hari oleh peserta didik baik di lingkungan sekolah maupun di luar lingkungan sekolah, maka nilai-nilai karakter perlu dijabarkan ke dalam sikap dan perilaku nyata yang bisa dilakukan oleh peserta didik dan sekaligus menjadi indikator dari nilai-nilai karakter trsebut. Lebih lengkapnya lihat tabel 4 (lampiran).

Pendidikan karakter adalah pendidikan seumur hidup, suatu proses menuju manusia yang sempurna. Oleh karena itu, pendidikan karakter membutuhkan teladan dan karisma sejak kecil. Masa paling sensitif dan menentukan adalah pendidikan keluarga, yang menjadi tanggung jawab orang tua. Di sisi lain, pendidikan karakter harus menjadi bagian integral dari pendidikan transfer generasi. Pendidikan adalah masalah kemanusiaan dan harus diselesaikan dari perspektif pembangunan manusia itu sendiri (Kartadinata, 2010)

Pendidikan karakter merupakan upaya yang dirancang dan dilaksanakan secara sistematis untuk membantu peserta didik memahami nilai-nilai perilaku manusia yang berhubungan dengan Tuhan Yang Maha Esa, diri sendiri, sesama manusia, lingkungan, dan kebangsaan yang terwujud dalam pikiran, sikap, perasaan, perkataan, dan perbuatan berdasarkan norma-norma agama, hukum, tata krama, budaya, dan adat istiadat. (Pranowo, 2012)

\section{SIMPULAN}

PAUD Fatma Kenangan adalah salah satu lembaga anak usia dini yang menerapan pilar pendidikan karakter berbasis sentra bahan alam yang melakukan pembiasaan seharihari dengan meningkakan sembilan pilar yang diambil dari sikap asmaul usna. Dengan ada nya penerapan pilar ini anak usia dini mampu menerapkan pilar tersebut dengan media yang 
telah disiapkan seperti air, tanah, batu-batuan dan lain sebagainya. Dengan itu akan memberikan pengaruh pada perkembangan anak sebegai bekal untuk masa yang mendatang.

\section{UCAPAN TERIMA KASIH}

Terima kasih kepada PAUD Fatma Kenanga, dosen pembimbing dan teman sejawat yang telah memberikan saran perbaikan artikel ini. Terkhusus kepada rekan yang membantu pengumpulan data.

\section{DAFTAR PUSTAKA}

Asmani, J. M. (2011). Buku Panduan Internalisasi Pendidikan Karakterdi Sekolah. Yogyakarta: Diva Press.

Basrowi, \& Suwandi. (2008). Memahami Penelitian Kualitatif. Jakarta: Rineka Cipta.

Budiarti, F. (2015). Analisis pembelajaran sentra bahan alam untuk mengembangkan kreativitas menempel anak usia 5-6 tahun. Jurnal Pendidikan dan Pembelajaran Khatulistiwa, $4,1-12$ Diambil dari https://jurnal.untan.ac.id/index.php/jpdpb/article/view/8641

Dwi Riyanti Danang Prasetyo, M. (2019). Pentingnya Pendidikan Karakter Melalui Keteladanan Guru. HARMONY: Jurnal Pembelajaran IPS dan PKN., 4, 19-32. Diambil dari https://journal.unnes.ac.id/sju/index.php/harmony/article/view/31153

Firmadani, F. (2020). Pendidikan Karakter, 31. Diambil dari https:// repository.penerbitwidina.com/media/327024-pendidikan-karakter9151af09.pdf

Iswantiningtyas, V. (2019). Penanaman Pendidikan Karakter pada Model Pembelajaran BCCT (Beyond Centers and Circle Time). Jurnal obsesi : Jurnal pendidikan Anak Usia Dini, 3(1), 110-116. https://doi.org/10.31004/obsesi.v3i1.106

Kartadinata. (2010). Mencari Bentuk Pendidikan Karakter Bangsa. Jurnal Fakultas Ilmu Pendidikan, Universitas Pendidikan Indonesia. https:// doi.org/10.33650/edureligia.v1i2.50

Kementerian Pendidikan dan Kebudayaan. (2013). Buku Tematik Terpadu Kurikulum 2013, Buku Siswa Kelas IV. Jakarta: Kemendikbud.

Lee, A. (2016). Implementing character education program through music and integrated activities in early childhood settings in Taiwan. International Journal of Music Education, 34(3), 340-351. https:// doi.org/10.1177/0255761414563195

Liyana, K. (2019). Media pembelajaran dalam proses pembelajaran digunakan untuk membantu didalam kegiatan belajar dan mengajar serta dapat membantu memberikan pengalaman konkret, memotivasi dan membangkitkan minat belajar anak. (Liyana \& Kurniawan, 2019). Jurnal Obsesi: Jurnal Pendidikan Anak Usia Dini, 3(1), 225. https://doi.org/10.31004/obsesi.v3i1.178

Mukhtar Latif. (2013). Pendidikan Anak Usia Dini. Jakarta: Kencana Prenada Media Group.

Muslich, M. (2011). Pendidikan Karakter: Menjawab Tantangan Krisis Multidimensional. Jurnal Pendidikan Agama Islam, 03, 84. https://doi.org/10.33650/edureligia.v1i2.50

Pranowo, D. D. (2012). Implementasi Pendidikan Karakter Kepedulian Dan Kerjasama Pada Matakuliah Keterampilan Berbicara Bahasa Prancis Dengan Metode Bermain Peran. Jurnal Pendidikan Karakter UNY, 4. https:/ / doi.org/10.21831/jpk.v2i2.1442

Prasetyo, N. (2011). Membangun Karakter Anak Usia Dini. Jurnal Pendidikan Agama Islam, 3, 5. Diambil dari http://repositori.kemdikbud.go.id/567/1/21 MEMBANGUN KARAKTER.pdf

Ramdhani, Y. 7 H. (2019). Proses pembelajaran di di PAUD menekankan semua aspek perkembangan berhasil dalam perkembangan anak usia dini. (Ramdhani, Yuliastri, Sari, \& Hasriah, 2019). Jurnal Obsesi : Jurnal Pendidikan Anak Usia Dini, 3(1), 153. https://doi.org/10.31004/obsesi.v3i1.108 
DOI: $10.31004 /$ obsesi.v6i3.1172

Rasyad, A. (2015). Developing a Parenting Training Model of Character Education for Young Learners from Poor Families by Using Transformative Learning Approach. International Education Studies, 8(8), 50-56. https:// doi.org/10.5539/ies.v8n8p50

Retnowati, E. (2008). Keterbatasan Memori dan Implikasinya dalam Mendesain Metode Pembelajaran Matematika. Jurnal Pendidikan. Diambil dari https://eprints.uny.ac.id/6895/1/P-1 Pendidikan (Adi Nur).pdf

Rusman. (2014). Model-Model Pembelajaran: Mengembangkan Profesionalisme Guru, 75.

Sobri Sutikno. (2009). Belajar dan Pembelajaran. Bandung: Prospect.

Sudjana, N. (2005). Dasar-Dasar Belajar Mengajar. Bandung: Sinar Baru Algensindo.

Sudrajat, A. (2011). Mengapa Pendidikan Karakter. Jurnal Pendidikan Karakter, 1, 48. https:/ / doi.org /10.21831/jpk.v1i1.1316

Sugiyono. (2006). Memahami Penelitian Kualitatif. Bandung: Alfabeta.

Sujiono, Y. N. S. B. (2010). Bermain Kreatif Berbasis Kecerdasan Jamak. Jaka: Indeks.

Sutarjo, \& Adisusilo. J.R.. (2014). Pembelajaran Nilai-Karakter: Kontruktivisme dan VCT sebagai Inovasi Pendekatan Pembelajaran Afektif. Jakarta: PT Raja Grafindo Persada.

Suyadi, \& Dahlia. (2014). Implementasi Kurikulum Paud 2013. Bandung: PT Remaja Rosdakarya.

Towoliu, I. D., Hartati, S., \& Hapidin, H. (2020). Pendidikan Karakter Berbasis Islam melalui Program Cinta Rosul pada Anak Taman Kanak-Kanak. Jurnal Obsesi: Jurnal Pendidikan Anak Usia Dini, 5(1), 521. https://doi.org/10.31004/obsesi.v5i1.618

Wina Sanjaya. (2011). Pendidikan Tindakan Kelas. Jakarta: Kencana Prenada Media Grup.

Zainal Aqib, \& Ahmad Amrullah. (2017). Pedoman Pendidikan Budaya dan Karakter Bangsa. Yogyakarta: Gama Media. 
Tabel 1. nilai-nilai budaya dan karakter bangsa menurut M. Yaumi (2014: 83)

\begin{tabular}{|c|c|c|}
\hline No & $\begin{array}{c}\text { Nilai-nilai } \\
\text { Budaya dan } \\
\text { Karakter Bangsa }\end{array}$ & Pengertian \\
\hline 1. & Religius & $\begin{array}{l}\text { Sikap dan perilaku yang patuh dalam melaksanakan ajaran agama yang } \\
\text { dianutnya, toleran terhadap pelaksanaan ibadah agama lain, dan hidup } \\
\text { rukun dengan pemeluk agama lain. }\end{array}$ \\
\hline 2. & Jujur & $\begin{array}{l}\text { Jujur perilaku yang didasarkan pada upaya menjadikan dirinya sebagai } \\
\text { orang yang selalu dapat dipercaya dalam perkataan, tindakan, dan } \\
\text { pekerjaan. }\end{array}$ \\
\hline 3. & Toleran & $\begin{array}{l}\text { Sikap dan tindakan yang menghargai perbedaan agama, suku, etnis, } \\
\text { pendapat, sikap, dan tindakan orang lain yang berbeda dari dirinya. }\end{array}$ \\
\hline 4. & Disiplin & $\begin{array}{l}\text { Tindakan yamg menunjukkan perilaku tertib dan patuh pada berbagai } \\
\text { peraturan dan ketentuan. }\end{array}$ \\
\hline 5. & Kerja keras & $\begin{array}{l}\text { Perilaku yang menunjukkan upaya sungguh-sungguh dalam mengatasi } \\
\text { berbagai hambatan belajar dan tugas, serta menyelesaikan tugas dengan } \\
\text { sebaik-baiknya. }\end{array}$ \\
\hline 6. & Kreatif & $\begin{array}{l}\text { Berfikir dan melakukan sesuatu untuk menghasilkan cara atau hasil } \\
\text { baru dari sesuatu yang dimiliki. }\end{array}$ \\
\hline 7. & Mandiri & $\begin{array}{l}\text { Sikap dan perilaku yang tidak mudah tergantung pada orang lain } \\
\text { dalam menyelesaikan tugas. }\end{array}$ \\
\hline 8. & Demokratis & $\begin{array}{l}\text { Cara berfikir, bersikap dan bertindah yang menilai sama hak dan } \\
\text { kewajiban dirinyadan orang lain. }\end{array}$ \\
\hline 9. & Rasa ingin tahu & $\begin{array}{l}\text { Sikap dan tindakan yang selalu beupaya intuk mengetahui lebih } \\
\text { mendalam dan meluas dari sesuatu yang dipelajarinya, dilihat dan } \\
\text { didengar. }\end{array}$ \\
\hline 10. & $\begin{array}{l}\text { Semangat } \\
\text { kebangsaan }\end{array}$ & $\begin{array}{l}\text { Cara berfikir, bertindak, dan berwawasan yang menempatkan } \\
\text { kepentingan bagsa dan negara diatas kepentingan diri dan } \\
\text { kelompoknya. }\end{array}$ \\
\hline 11. & Cinta tanah air & $\begin{array}{l}\text { Cara berfikir, bersikap dan berbuat yang menunjukkan kesetiaan, } \\
\text { kepedulian, dan penghargaan yang tinggi terhadap bahasa, lingkjungan } \\
\text { fisik, sosial, budaya, ekomomi dan politik bangsa. }\end{array}$ \\
\hline 12. & $\begin{array}{l}\text { Menghargai } \\
\text { prestasi }\end{array}$ & $\begin{array}{l}\text { Sikap dan tindakan yang mendorong dirinya untuk menghasilkan } \\
\text { sesuatu yang beguna bagi masyarakat, dan mengakui, serta } \\
\text { menghormati keberhasilan orang lain. }\end{array}$ \\
\hline 13. & $\begin{array}{l}\text { Bersahabat/ko } \\
\text { munikatif }\end{array}$ & $\begin{array}{l}\text { Tindakan yang memperlihatkan rasa senanb } \backslash \mathrm{g} \text { berbicara, bergaul, dan } \\
\text { bekerja sama dengan orang lain. }\end{array}$ \\
\hline 14. & Cinta damai & $\begin{array}{l}\text { Sikap, perkataan, dan tindakan yang menyebabkan orang lain mersa } \\
\text { senang sdan aman atas kehadiran dirinya. }\end{array}$ \\
\hline 15. & $\begin{array}{l}\text { Peduli } \\
\text { lingkungan }\end{array}$ & $\begin{array}{l}\text { Sikap dan tindaka yang selalu berupaya mencegah kerusakan pada } \\
\text { lingkungan alam disekitarnya, dan mengembangkan upata-upaya } \\
\text { untul memperbaiki kerusakan alam yang sudah tejadi. }\end{array}$ \\
\hline 16. & Peduli s & Sikap dan tinfakan yang selalu ingim memberi bantuan pada orang lain. \\
\hline 17. & Tanggung jawab & $\begin{array}{l}\text { Sikap dan perilaku seseorang untuk melaksanakan tugas dan } \\
\text { kewajibanya. }\end{array}$ \\
\hline
\end{tabular}




\section{Tabel 2. Alat permainan yang digunakan di sentra bahan alam}

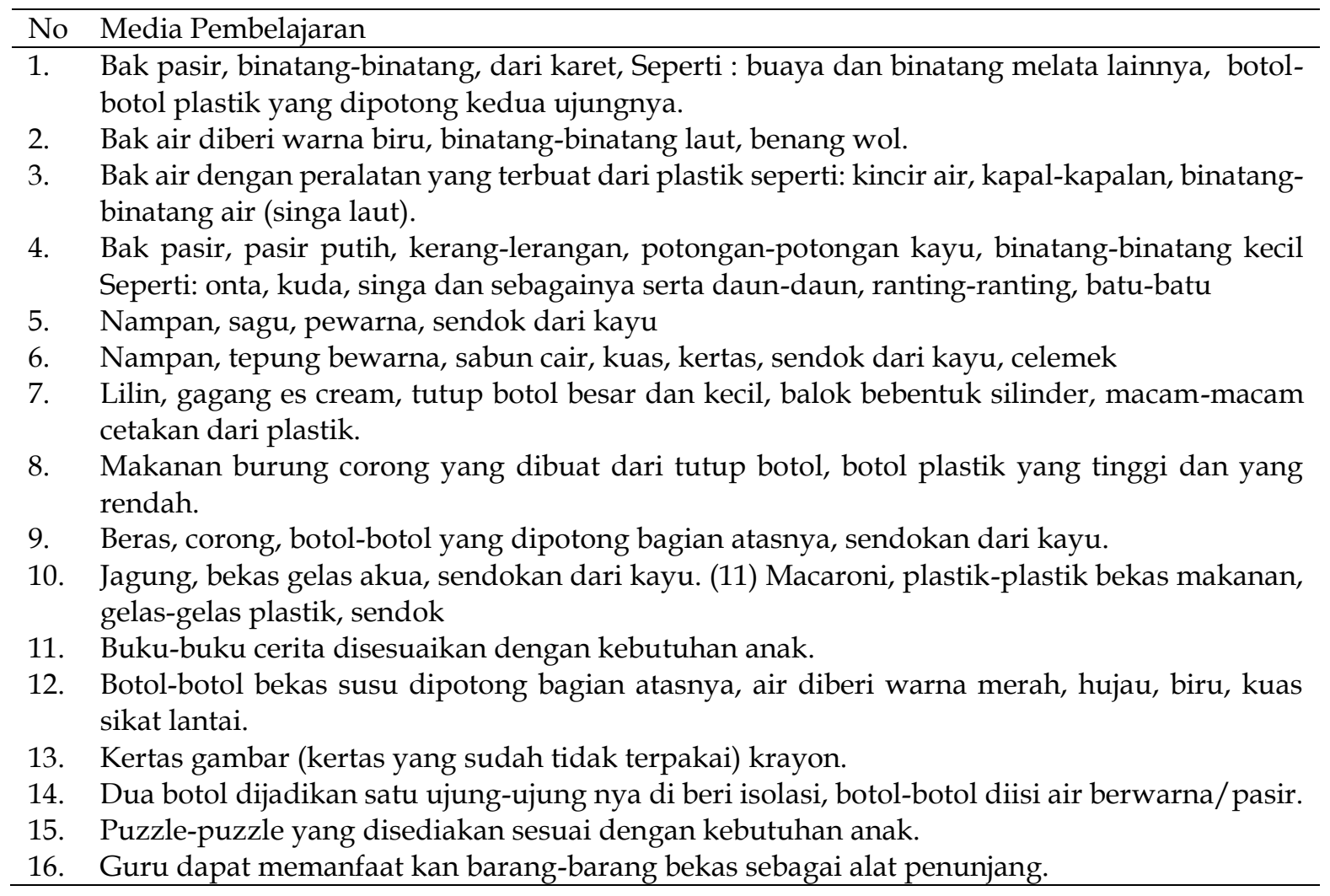

Tabel 3. Pilar pendidikan karakter dalam kehidupan sehari-harinya

\begin{tabular}{|c|c|c|}
\hline No & $\begin{array}{l}\text { Pilar Pendidikan } \\
\text { Karakter }\end{array}$ & Keterangan \\
\hline 1. & $\begin{array}{l}\text { Pilar Cinta Tuhan } \\
\text { dan Segenap } \\
\text { Ciptaan-Nya }\end{array}$ & $\begin{array}{l}\text { Dapat dilihat ketika peserta didik melaksanakan sholat dhuha, mengenal } \\
\text { ciptaan Tuhan seperti tumbuhan dan hewan, mengenal sifat-sifat Allah, } \\
\text { mengetahui nama-nama Nabi, mengetahui rukun iman, mengetahui } \\
\text { rukun Islam. }\end{array}$ \\
\hline 2. & $\begin{array}{l}\text { Perilaku } \\
\text { tanggung jawab }\end{array}$ & $\begin{array}{l}\text { Peserta didik mau minta maaf karena kesalahannya, membereskan } \\
\text { mainan ketika selesai bermain, membersihkan sisa-sisa makanan ketika } \\
\text { selesai makan. }\end{array}$ \\
\hline 3. & Perilaku disi & at waktu, pulang tepat waktu. \\
\hline 4. & Perilaku ma & $\begin{array}{l}\text { kan sepatu, memakai tas dan sepatu sendiri, } \\
\text { ri. }\end{array}$ \\
\hline 5. & Perila & \\
\hline 6. & Perilaku amanah & $\begin{array}{l}\text { ikan pesan titipan dengan baik se } \\
\text { an. }\end{array}$ \\
\hline 7. & $\begin{array}{l}\text { Perilaku } \\
\text { diplomatis }\end{array}$ & $\begin{array}{l}\text { Peserta didik mendiskusikan dengan teman sekelompoknya mengenai } \\
\text { kegiatannya. }\end{array}$ \\
\hline 8. & Perilaku hor & dengan \\
\hline 9. & Peril & \\
\hline 10. & $\begin{array}{l}\text { Perilaku } \\
\text { sayang }\end{array}$ & gi pendidik dan teman-teman. \\
\hline 11. & & $\begin{array}{l}\text { Membuang sampah ke tempat sampah, menawarkan bantuan pada guru } \\
\text { ataupun teman, suka berkomunikasi, membantu teman yang } \\
\text { membutuhkan. }\end{array}$ \\
\hline 12. & $\begin{array}{l}\text { Perilaku } \\
\text { kerjasama: }\end{array}$ & $\begin{array}{l}\text { Melakukan kegiatan bersama/membuat proyek bersama-sama. Pilar } \\
\text { percaya diri, kreatif, dan kerja keras. }\end{array}$ \\
\hline
\end{tabular}




\begin{tabular}{|c|c|c|}
\hline No & $\begin{array}{l}\text { Pilar Pendidikan } \\
\text { Karakter }\end{array}$ & gan \\
\hline 13. & $\begin{array}{l}\text { Perilaku percaya } \\
\text { diri }\end{array}$ & $\begin{array}{l}\text { Peserta didik berani mengungkapkan pendapatnya, berani tampil, berani } \\
\text { bertanya, berani menyampaikan keinginannya. }\end{array}$ \\
\hline 14. & erilaku kreatif & mpian-impiannya. \\
\hline 15. & $\begin{array}{l}\text { Perilaku } \\
\text { keras }\end{array}$ & mal. \\
\hline 16. & Perilaku keadilan & $\begin{array}{l}\text { Misalnya peserta didik } 1 \\
\text { kepada teman-temannya } \\
\text { semuanya dibagi ke tem }\end{array}$ \\
\hline 17. & $\begin{array}{l}\text { Perilaku } \\
\text { kepemimpinan }\end{array}$ & innya, menjadi contoh untuk temannya. \\
\hline 18. & $\begin{array}{l}\text { Pilar Baik dan } \\
\text { Rendah hati }\end{array}$ & lain. \\
\hline 19. & Perilaku toleransi & $\begin{array}{l}\text { Peserta didik mau main bersama temannya yang secara fisik tidak } \\
\text { normal. }\end{array}$ \\
\hline 20. & $\begin{array}{l}\text { Perilaku } \\
\text { damai }\end{array}$ & $\begin{array}{l}\text { Bisa menjaga emosi negatifnya ketika bermain, jika ada konflik segera } \\
\text { menyelesaikannya dengan baik. }\end{array}$ \\
\hline 21. & $\begin{array}{l}\text { Perilaku } \\
\text { persatuan, }\end{array}$ & $\begin{array}{l}\text { Cinta terhadap negara indonesia misalnya menyanyikan lagu-lagu } \\
\text { kemerdekaan, lagu nasional, mengenang para pahlawan, menanamkan } \\
\text { jiwa persatuan. }\end{array}$ \\
\hline
\end{tabular}

Tabel 4. nilai-nilai karakter bisa diterapkan dalam kehidupan sehari-hari oleh peserta didik menurut Marzuki dalam (Dwi Riyanti Danang Prasetyo, 2019)

\begin{tabular}{|c|c|c|}
\hline No & $\begin{array}{c}\text { Nilai } \\
\text { Karakter }\end{array}$ & Pengertian \\
\hline 1. & $\begin{array}{l}\text { Taat kepada } \\
\text { Allah }\end{array}$ & $\begin{array}{l}\text { Melaksanakan perintah Allah secara ikhlas, dan meninggalkan semua } \\
\text { larangannya. }\end{array}$ \\
\hline 2. & $\begin{array}{l}\text { Tanggung } \\
\text { jawab }\end{array}$ & $\begin{array}{l}\text { Menyelesaikan semua kewajiban, tidak suka menyalahkan orang lain, tidak lari } \\
\text { dari tugas yang harus diselesaikan, dan berani mengambil resiko. }\end{array}$ \\
\hline 3. & Disiplin & $\begin{array}{l}\text { Selalu datang tepat waktu, jika berhalangan hadir memberi tahu, taat pada } \\
\text { peraturan sekolah, taat pada peraturan lalu lintas. }\end{array}$ \\
\hline 4. & Mandiri & $\begin{array}{l}\text { Bekerja keras dalam belajar, melakukan pekerjaan/tugas secara mandiri, tidak } \\
\text { mau bergantung pada orang lain. }\end{array}$ \\
\hline 5. & Jujur & $\begin{array}{l}\text { Berkata dan berbuat apa adanya, mengatakan yang benar itu benar, mengatakan } \\
\text { yang salah itu salah. }\end{array}$ \\
\hline 6. & Hormat & $\begin{array}{l}\text { Hormat pada guru dan orang tua, berkata dengan halus, berperilaku dengan } \\
\text { sopan. }\end{array}$ \\
\hline 7. & Santun & Berkata-kata dengan halus, berperilaku dengan sopan, berpakaian dengan sopan. \\
\hline 8. & $\begin{array}{l}\text { Menyayangi } \\
\text { orang lain }\end{array}$ & $\begin{array}{l}\text { Suka menolong atau membantu orang yang kekurangan, tidak membiarkan orang } \\
\text { lain menderita, selalu berdoa dmi kebaikan orang lain. }\end{array}$ \\
\hline 9. & Peduli & $\begin{array}{l}\text { Penuh perhatian pada orang lain, menolong orang yang celaka, memberi makan } \\
\text { orang yang kelaparan. }\end{array}$ \\
\hline 10. & Percaya diri & $\begin{array}{l}\text { Berani melakukan sesuatu karena merasa mampu, tidak ragu untuk berbuat } \\
\text { sesuatu yang diyakini mampu dilakukan, tidak selalu menggantungkan bantuan } \\
\text { pada orang lain. }\end{array}$ \\
\hline 11. & Kreatif & $\begin{array}{l}\text { Terampil mengerjakan sesuatu, menemukan cara praktis dalam menyelesaikan } \\
\text { sesuatu, tidak selalu tergantung pada cara dan karya orang lain. }\end{array}$ \\
\hline 12. & Kerja keras & Semangat dalam bekerja, semangat dalam belajar, tidak bermalas-malasan. \\
\hline 13. & Adil & $\begin{array}{l}\text { Bersikap sama kepada semua teman, membagi sesuatu secara sama dan seimbang, } \\
\text { tidak pilih kasih, tidak berbuat aniaya. }\end{array}$ \\
\hline 14. & Rendah hati & $\begin{array}{l}\text { Berpenampilan sederhana, selalu merasa tidak bisa meskipun sebenarnya bisa, } \\
\text { tidak menganggap remeh orang lain. }\end{array}$ \\
\hline 15. & Toleransi & $\begin{array}{l}\text { Tidak memaksakan kehendak pada orang lain, menghormati orang lain yang } \\
\text { berbeda dengannya, mengakui perbedaan dengan mengambil sikap positif. }\end{array}$ \\
\hline 16. & Qonaah & $\begin{array}{l}\text { Menerima semua ketentuan Allah, merasa cukup dengan apa yang dimiliki, } \\
\text { menerima semua keputusan dengan rela dan sabar serta tidak putus asa. }\end{array}$ \\
\hline
\end{tabular}

